Open Access

\title{
Does form-focused instruction really make a difference? Potential effectiveness in Jordanian EFL learners' linguistic and pragmatic knowledge acquisition
}

\author{
Ruba Fahmi Bataineh", Fatima Rasheed Al-Qeyam and Oqlah Mahmoud Smadi
}

\author{
* Correspondence: rubab@yu.edu.jo \\ Department of Curriculum and \\ Instruction, Yarmouk University, \\ Irbid, Jordan
}

\begin{abstract}
This study examines the potential effectiveness of form-focused instruction (henceforth, FFI) in developing Jordanian EFL learners' linguistic and pragmatic knowledge. Forty-seven college students of nursing were divided into two groups: an experimental group of twenty-seven students received FFI on grammatical structures (viz. the simple present, gerunds, modal auxiliaries, questions, the present perfect and conditionals type II) and speech acts (viz. apology, request, and suggestion) and a control group of twenty students taught per the guidelines of the prescribed textbook. The data were analyzed using descriptive statistics, Analysis of Covariance (ANCOVA), and Multivariate Analysis of Covariance (MANCOVA). The findings revealed that FFI positively affects students' linguistic and pragmatic knowledge, more so for pragmatic than linguistic knowledge. Several pedagogical implications and recommendations are put forth.
\end{abstract}

Keywords: Form-focused instruction, Grammar, Linguistic knowledge, Pragmatic knowledge, Speech acts, Tertiary education

\section{Introduction and background}

Language comprises five major components (viz., phonology, morphology, syntax, semantics, and pragmatics) the knowledge of which subsumes language competence. The goal of language teaching today is language for communication (Brown, 2001; Richards \& Rodgers, 2006). Hence, effective language teaching strives to mobilize various language components to build the learner's communicative competence.

Communicative Language Teaching (henceforth, CLT) emphasizes learning for accurate and fluent communication (Binder, 1990, 1991; Richard \& Rodgers, 2006), while accuracy (aka, formal correctness) entails raising the learner's awareness of form for the mastery of structures and rules of language usage (e.g. using vocabulary, pronouncing a word), and fluency (aka, communicative effectiveness) entails the acquisition of the rules of language use.

Research (e.g., Binder, 1996; Wolf, 2001) suggests that fluency is instrumental for critical learning, as it serves as a catalyst for retention and maintenance of skills and knowledge long after formal learning has ended, endurance to undistractedly maintain

(c) The Author(s). 2017 Open Access This article is distributed under the terms of the Creative Commons Attribution 4.0 International License (http://creativecommons.org/licenses/by/4.0/), which permits unrestricted use, distribution, and reproduction in any medium, provided you give appropriate credit to the original author(s) and the source, provide a link to the Creative Commons license, and indicate if changes were made. 
what has been learned for extended periods of time, and application of knowledge and skills in novel contexts. However, a combination of fluency and accuracy (aka accuracy at appropriate speed) is a significant indicator of mastery, as it helps teachers determine which of their students have, or have not, mastered a certain skill (Binder, 2003; Chiesa \& Robertson, 2000).

The acquisition of linguistic competence, defined as the knowledge about the grammar of a language (Chomsky, 1980), has traditionally been the focus of language teaching. Grammar instruction is believed to promote linguistic competence which is, in turn, an integral part of communicative competence (McKay, 1985).

Grammar instruction, albeit rife with controversy, has been a matter of emphasis in the language classroom. Rutherford (1980) and Westney (1994) claim that language teachers and learners alike should be aware that language is governed by rules which should be made available to learners whenever needed. Hence, pedagogical grammar, or the description of the grammar of a language for teaching and learning purposes, is instrumental for teaching and learning language.

Communicative competence is what language learners need to know about a language to communicate effectively in various situations (Hymes, 1983; Savignon, 1976). It comprises a three-tiered matrix of shared knowledge, linguistic knowledge, interaction skills, and cultural knowledge (Saville-Troike, 2003) needed for effective communication. However, even though the acquisition of linguistic competence is encompassed in the acquisition of communicative competence (Savignon, 1976), the mere acquisition of linguistic competence hardly leads to the acquisition of communicative competence.

Pragmatic competence is another vital component of communicative competence. Learners need be aware of how to develop their pragmatic knowledge in the foreign language because language use varies across contexts. McKay (1985) argues that language functions need be addressed in the classroom because language is meant to fulfill certain functions (e.g., making suggestions, refusing, inviting).

Research (e.g., Bardovi-Harlig, Hartford, Mahan-Taylor, Morgan, \& Raynolds 1991; Cutting, 2008; Huang, 2010) suggests that language learners need pragmatic instruction to gain exposure to samples of social, cultural, and discourse conventions of the target language. In fact, pragmatic instruction is imperative, as form and meaning are not always directly matched.

In other words, an utterance, beyond its literal meaning, may be intended per factors related to the interlocutors and the context of the exchange. The speaker fulfills certain functions or actions through language use (Austin, 1962), hence illocutionary speech acts (e.g., apologizing, blaming, congratulating, joking, nagging, promising). According to Gumperz and Roberts (1980, p.1), communication breakdowns are more the result of diverse conventions in the use of English than the result of a flawed accent or incomplete structural knowledge.

People from different cultural backgrounds may speak a variety of English characterized by certain conventions. It is when attitude and meaning are conveyed through one set of conventions and interpreted through another that breakdowns in communication may occur.

Speech acts are not only rule-governed but also comprised of three dimensions (viz., utterance, meaning, action), which is the crux of pragmatic knowledge. As awareness of 
pragmatic knowledge is instrumental for language learners and teachers alike, crosscultural differences have evoked much interest in the foreign language classroom (Bataineh, 2001; Bataineh \& Bataineh, 2006, 2008).

Pragmatic instruction potentially fosters the learner's ability to use language appropriately across a host of real-life contexts. As pragmatic instruction highlights the similarities and differences of language use in the native and target languages, its integration in foreign language instruction is a potential catalyst for language learning, both at the grammatical and functional levels (Bardovi-Harlig et al., 1991; McKay, 1985; Nivis, 2013; Simpson, 1997).

Form-focused instruction (FFI), also known as focus on form(s) (Long, 1991), analytic teaching (Lyster, 1994), and negotiation of form (Lyster, 2001), is defined as "any pedagogical effort which is used to draw the learners' attention to language forms either implicitly or explicitly" (Spada, 1997, p.73), and as "any planned or incidental instructional activity that is intended to induce language learners to pay attention to linguistic form" (Ellis, 2001, p.2).

What makes FFI a promising endeavor in foreign language teaching is its potential to draw the learner's attention to recurring forms during the lesson, hence attending to both form and communicative meaning (Long, 1991, 2000). Unlike the GrammarTranslation Approach, which divides language into discrete segments with no regard to meaning, the FFI lesson responds to learners' needs (Long, 1991), as communicative tasks and meaningful practice blend in activities which draw the learner's attention to language forms (Schmidt's (1990) consciousness-raising by noticing) to promote fluency and accuracy alike (Fotos \& Nassaji, 2011).

A plethora of empirical research suggests that FFI is effective in the foreign language classroom. Lingli and Wannaruk (2010), Hernández (2011), and Parviz and Gorjian (2013) reported that even though explicit instruction and implicit instruction are effective for the acquisition of linguistic and pragmatic knowledge, explicit instruction or a combination of the two is relatively more effective. Similarly, Abadikhah and Shahriyarpour (2012), Abadikhah and Shahriyarpour (2012) Spada, Jessop, Spada, Jessop, Tomita, Suzuki, and Valeo (2014), and Rafieyan, Sharafi-Nejad, and Eng (2014) reported a positive FFI effect on the acquisition of grammatical knowledge, automaticity, and fluency especially when more than one technique are combined.

FFI lends itself readily to foreign language learning, as language is easier to remember when it is noticed (Williams, 1999; Yu, 2011) and rehearsed for storage in the long-term memory (Dahlen \& Caldwell-Harris, 2013; Sanatullova-Allison, 2014; Spada \& Lightbown, 2008). The combination of noticing and rehearsal is essential, as cognitive processes connect the information in the short-term memory with that previously stored in the long-term memory and into the learners' schemata (Ellis, 2002; Williams, 1999).

This research targets only three (viz., consciousness-raising tasks, input enhancement, and task-essential language) of the eleven (viz., input flood, task-essential language, input enhancement, negotiation, recast, output enhancement, interaction enhancement, dictogloss, consciousness-raising tasks, input processing, and garden path) FFI techniques highlighted in the literature (Doughty \& Williams, 1998). Targeting these techniques was driven by the feasibility of carrying them out within the time and content constraints of the treatment. 
Consciousness-raising (CR) comprises providing students with explicit instruction of the form and function under study to help them notice language features they may not notice otherwise and, thus, build conscious knowledge of how language works (Harley, 1998; Svalberg, 2013). In CR, learners do not produce language but rather engage in tasks to become aware of specific linguistic features and, ultimately, the way language works (Thornbury, 2001). Input enhancement (IE), the most unobtrusive of all formfocused techniques (e.g., Doughty \& Williams, 1998), involves typographical enhancement to draw the learners' attention to the form by font manipulation (e.g., coloring, highlighting, underlining) in the text (Long \& Robinson, 1998; Sharwood-Smith, 1993). Similarly, task-essential (TE) language comprises using the forms under study for the completion of tasks (Doughty \& Williams, 1998).

\section{Problem, purpose, and questions of the study}

Learners of English as a foreign language experience a lot of difficulty, and Jordanian learners are no exception. They are reported to suffer from weaknesses in both language structures (e.g., Al-Damiree \& Bataineh, 2016; Al-Qeyam, Bataineh, \& Smadi, 2016; Bataineh \& Mayyas, 2017) and functions (e.g., Bataineh, 2001; Bataineh \& Bataineh, 2006 2008) as they strive to use English for real-life communication. The premise of this research is that Jordanian EFL learners need language instruction that fosters linguistic and pragmatic competences alike and provides authentic opportunities for communication.

Previous local research (e.g., Assaf, Al-Shboul, \& Alodwan, 2012; Huwari \& AlShboul, 2015) has examined the potential CLT in foreign language teaching in Jordan. However, very few studies (e.g., Al-Qeyam, Bataineh, \& Smadi, , 2016) were devoted to the potential effectiveness of FFI. Similarly, this research examines the potential effect of FFI on Jordanian tertiary-level students' linguistic and pragmatic knowledge acquisition. More specifically, two questions are addressed:

1. To what extent, if any, does form-focused instruction affect Jordanian EFL students' acquisition of linguistic and pragmatic knowledge?

2. Are there any statistically significant differences in the students' gain in linguistic and pragmatic knowledge, which can be attributed to instruction?

\section{Significance and limitations of the study}

This study is probably one of the first few to examine the potential effectiveness of FFI in the Jordanian EFL context. Its findings may offer teachers and students new techniques for teaching grammar and pragmatics in the English language classroom. These findings are hoped to break new grounds for further investigations in EFL since it is one of the first to address specific aspects of language competence using three FFI techniques.

As this research is limited in scope and sample to examining the effect of three (viz., consciousness-raising tasks, input enhancement, and task-essential language) out of eleven FFI techniques on linguistic (viz. the simple present, gerunds, modal auxiliaries, questions, the present perfect and conditionals type II) and pragmatic (viz. apology, request, and suggestion) knowledge acquisition of a convenient sample of 47 students from an EFL university course, further research may examine other grammatical 
structures and speech acts in various levels of students. This research is further limited in presentation, as it discusses the six grammatical aspects and the three speech acts as one construct each representing one type of knowledge.

\section{Method and procedures}

\section{Design and sampling}

This study adopts a quasi-experimental design. A convenience sample of two intact sections of an EFL course at $\mathrm{Al}$ al-Bayt University, Jordan, were divided into two groups: a control group of 20 students and an experimental group of 27 students.

\section{Instrumentation and data collection}

For data collection, two pre-/post tests were designed by the researchers: a 35-item grammatical structures test (GST), targeting the simple present, gerund, modal auxiliaries, questions, present perfect, and conditionals/type II and a 30-scenario Discourse Completion Task (DCT) divided equally among the speech acts of apology, request, and suggestion.

To establish their validity, the instruments and the instructional content were reviewed and examined by a jury of university professors of linguistics, curriculum and instruction and measurement and evaluation who judged the appropriateness of the instruments and instructional content for the purpose of the study. Similarly, to establish their reliability, both the GST and DCT were administered twice to a group of 15 students (from the same course in the preceding semester) with a three-week lapse. The reliability coefficients were 0.78 and 0.83 for the GST and DCT, respectively.

\section{Instructing the two groups}

According to its description, the course aims at improving nurses' English for the workplace, fostering their confidence in using English, and enabling them to communicate with people in their profession (et al.-Bayt University, 2015). The course reportedly exposes students to nursing-related concepts and expressions but does not focus much on grammar and pragmatics.

The participants were initially pre-tested to determine potential differences among them, and an independent samples t-test was used to assure equivalence between the two groups. The groups were presumed equivalent as the values of Levene's Test of Equality of Variance were 0.429 and 0.217 for the GST and DCT (both greater than $\alpha$ ).

The control group was taught by the original course instructor whereas the experimental group was taught by the second researcher. Both instructors had an MA degree in Linguistics (at the time of the study) and similar experience in teaching EFL courses. The control group was taught per the guidelines of the textbook, English for Careers: Nursing 1 (Grice \& Maheen, 2007), as follows:

1. The instructor started the lesson with a warm-up exercise (usually a topic-related picture and several questions about it).

2. The students did the exercises under the guidance of the instructor who read them and elicited students' answers.

3. The students read the passages aloud and the instructor engaged them in class discussion. 
4. For the listening exercises, the instructor read the scripts and discussed the questions with the students.

5. The instructor explained the structures (outlined in the Language Spot of the unit) and elicited students' responses on specific items.

6. The instructor assigned a writing essay as homework after explaining the requirements of the exercise to the students.

On the other hand, the experimental group was taught the grammatical structures and speech acts through an eight-week, researcher-designed, FFI-based instructional treatment. The content of the treatment was based on the course book, Oxford English for Careers Nursing (1), itself (Grice \& Maheen, 2009). The 60-min lessons proceeded as follows:

1. The lesson began by discussing the material of the textbook.

2. Each lesson a grammatical structure was introduced, explained, and then matched with a speech act. The goal was to enable students to notice each speech act and its underlying structures through consciousness-raising tasks (Harley, 1998).

3. At the end of each lesson, a dialogues with the speech act underlined, was presented per the input enhancement technique to draw the participants' attention to the speech act (Long \& Robinson, 1998).

4. The participants were then asked to read or role-play the dialogues in pairs or small groups.

5. After studying a speech act and its underlying structures, students engaged in taskessential language in which they completed tasks on the structures in question.

Both groups of participants were post-tested to determine the potential effect of FFI on their linguistic and pragmatic knowledge.

\section{Findings}

The purpose of this study is to investigate the effect of FFI on Jordanian EFL university students' linguistic and pragmatic knowledge acquisition. The data were analyzed and the findings discussed per the questions of the research.

To answer the first question, which examines the potential FFI effect on linguistic and pragmatic knowledge acquisition, means and standard deviations of the students' scores on the pre- and post-tests, along with the adjusted mean scores and standard errors on the post-test, were calculated for both the GST per the method of instruction, as shown in Table 1.

Table 1 Means and Standard Deviations of the Students' Performance on the Pre- and Post- GST

\begin{tabular}{|c|c|c|c|c|c|c|c|c|}
\hline \multirow[t]{2}{*}{ Test } & \multirow[t]{2}{*}{ Group } & \multirow[t]{2}{*}{$n$} & \multicolumn{2}{|c|}{ Pre- test } & \multicolumn{2}{|c|}{ Post- test } & \multirow[t]{2}{*}{ Adjusted mean } & \multirow[t]{2}{*}{ SE } \\
\hline & & & Mean & SD & Mean & SD & & \\
\hline \multirow[t]{2}{*}{ GST } & Control & 20 & 18.15 & 13.11 & 18.60 & 13.04 & 19.53 & 2.50 \\
\hline & Experimental & 27 & 20.33 & 10.72 & 29.96 & 14.86 & 29.27 & 2.15 \\
\hline \multirow[t]{2}{*}{$\mathrm{DCT}$} & Control & 20 & 32.10 & 9.15 & 24.80 & 11.91 & 23.41 & 2.34 \\
\hline & Experimental & 27 & 28.51 & 12.23 & 40.70 & 13.26 & 41.73 & 2.01 \\
\hline
\end{tabular}


Table 1 shows observed differences in the mean and adjusted mean scores of the two groups which seems to suggest a gain in the participants' linguistic and pragmatic knowledge in favor of the experimental group. For further examination of the results, ANCOVA was used to analyze students' scores in the tests as shown in Table 2.

Table 2 shows a statistically significant difference in students' scores in both the GST and DCT (at $\alpha=0.05)$ in favor of the experimental group $(\mathrm{F}=8.62, \mathrm{df}=46$, $P=0.005),(\mathrm{F}=34.57, \mathrm{df}=46, P=0.000)$, which seems to suggest that FFI is a catalyst for both linguistic and pragmatic knowledge acquisition.

To answer the second research question, which sought potentially significant differences in the students' gain in linguistic and pragmatic knowledge, means and standard deviations of the students' pre- and post- GST and DCT scores, along with the adjusted mean scores and the standard errors of the post-test, were calculated for both groups, as shown in Table 3.

Table 3 shows differences between the mean scores and standard deviations of students' scores in the pre- tests and post- tests of the GST and DCT. Moreover, the adjusted means of the post- tests show differences in scores of the GST and DCT between the control and experimental groups due to FFI. For further examination and comprehensive results, MANCOVA was used as shown in Table 4.

Table 4 shows a statistically significant difference (at $\alpha=0.05)$ in the students' scores in the post- GST and DCT, which can be attributed to FFI. Table 4 also reveals a larger effect for FFI on pragmatic than on linguistic knowledge acquisition.

\section{Results and Discussion}

The analysis of the data revealed that the learners in the FFI group outperformed those in the control group on both the grammatical structures and the discourse completion post-tests. The analysis further revealed that FFI has a larger effect on the participants' pragmatic knowledge acquisition than on their linguistic knowledge acquisition.

The control group was taught per the guidelines of the Teacher's Book which focuses little on grammar, with one lesson per unit about grammar and few subsequent exercises, and not at all on speech acts. By contrast, the participants of the experimental group were explicitly instructed, through task-essential language and consciousness-raising, to notice language forms, change them into intake, and store them in long-term memory to later retrieve in language use. Input enhancement was then experienced through authentic, speech act-rich dialogues which were read and discussed in small groups and with the class. The participants then worked in pairs to write dialogues to role-play, which allowed them opportunities to put what they have learnt into practice.

Table 2 ANCOVA of the Students' Scores on the Post- GST and DCT

\begin{tabular}{|c|c|c|c|c|c|c|c|}
\hline Test & Source & Sum of Squares & $\mathrm{df}$ & Mean Squares & $\mathrm{F}$ & Sig. & Partial Eta Squared \\
\hline \multirow[t]{3}{*}{ GST } & Way & 1079.68 & 1 & 1079.68 & 8.62 & $0.005^{*}$ & 0.164 \\
\hline & Error & 5508.37 & 44 & 125.19 & & & \\
\hline & Corrected Total & $10,467.23$ & 46 & & & & \\
\hline \multirow[t]{3}{*}{$\mathrm{DCT}$} & Way & 3754.14 & 1 & 3754.14 & 34.57 & $0.000^{*}$ & 0.44 \\
\hline & Error & 4776.93 & 44 & 108.56 & & & \\
\hline & Corrected Total & $10,174.80$ & 46 & & & & \\
\hline
\end{tabular}

$n=47$

${ }^{*}$ significant (at $a=0.05$ ) 
Table 3 Means and Standard Deviations of the Students' Pre- and Post- GST and DCT

\begin{tabular}{|c|c|c|c|c|c|c|c|}
\hline Source & Variable & Sum of squares & Df & Mean square & $\mathrm{F}$ & Sig. & Partial Eta Squared \\
\hline \multirow[t]{2}{*}{ Way } & Linguistic Knowledge & 1562.47 & 1 & 1562.47 & 15.40 & $0.000^{*}$ & 0.264 \\
\hline & Pragmatic Knowledge & 3205.17 & 1 & 3205.17 & 31.68 & $0.000^{*}$ & 0.424 \\
\hline \multirow[t]{2}{*}{ Error } & Linguistic Knowledge & 4360.29 & 43 & 101.40 & & & \\
\hline & Pragmatic Knowledge & 4349.37 & 43 & 101.14 & & & \\
\hline \multirow[t]{2}{*}{ Corrected Total } & Linguistic Knowledge & $10,467.23$ & 46 & & & & \\
\hline & Pragmatic Knowledge & $10,174.80$ & 46 & & & & \\
\hline
\end{tabular}

The cooperative nature of these tasks involved a lot of interaction, which may have allowed hands-on manipulation of both linguistic and pragmatic knowledge, especially when interacting with more proficient peers. This acquired knowledge may be readily transferable when the participants find themselves in real-life situations which require them to do so, as nurses, according to Guttman (2004), need to be linguistically competent to meet the requirements of their profession.

Unlike the students in the FFI group, those in the control group, who did not engage in group work, did not reap the benefit of cooperative language learning. In other words, they were denied opportunities to share their knowledge and help one another remember language forms, which potentially leads to better language learning.

The FFI group's superior performance corroborates previous research findings (e.g. Hernández, 2008, 2011; Lingli \& Wannaruk, 2010; Parviz \& Gorjian, 2013; Rafieyan et al., 2014; Spada et al., 2014) which suggest a marked positive FFI effect on the acquisition of grammar and pragmatics.

The second research question sought potentially significant differences in the students' gain in linguistic and pragmatic knowledge. Statistically significant differences were found in the FFI group's performance on the GST and DCT, but more so on the DCT, which may suggest that FFI has a greater effect on pragmatic than on linguistic knowledge acquisition.

This difference may be attributed to the integration of more than one FFI technique in teaching the speech acts, as grammatical structures and speech acts were presented through input enhancement dialogues to enable the learners to recognize the speech act and its underlying form in actual use. Consistent with Izumi's (2002) findings, combining FFI techniques potentially improves learning through cognitive engagement, which enables learners to store knowledge in a more memorable manner.

Table 4 MANCOVA of the Students' Scores on the Post- GST and DCT

\begin{tabular}{lllllllc}
\hline Source & Variable & Sum of squares & Df & Mean squares & $F$ & Sig. & Partial Eta Squared \\
\hline Way & Linguistic Knowledge & 1562.47 & 1 & 1562.47 & 15.40 & $0.000^{*}$ & 0.264 \\
& Pragmatic Knowledge & 3205.17 & 1 & 3205.17 & 31.68 & $0.000^{*}$ & 0.424 \\
Error & Linguistic Knowledge & 4360.29 & 43 & 101.40 & & & \\
& Pragmatic Knowledge & 4349.37 & 43 & 101.14 & & & \\
Corrected Total & Linguistic Knowledge & $10,467.23$ & 46 & & & & \\
& Pragmatic Knowledge & $10,174.80$ & 46 & & & & \\
& & &
\end{tabular}

$\mathrm{n}=47$

${ }^{*}$ significant (at $\alpha=0.05$ ) 
Moreover, the life-like input enhancement dialogues may have provided learners with opportunities for linguistic and pragmatic practice for first-hand experience of utility of these speech acts in everyday life. These opportunities are instrumental for developing pragmatic knowledge (Omaggio-Hadley, 2001; Simpson, 1997), as learners are provided with opportunities to practice a variety of functions likely to be encountered in the target language.

Furthermore, the participants were found to be more interested in learning speech acts than grammar, which may be partly responsible for the relatively superior pragmatic knowledge acquisition. The participants seemed to realize the utility of learning the speech acts in their lives and career, which culminated in immense interest in learning and producing speech acts.

\section{Conclusions and recommendation}

The contribution of this research has been four-fold. First, explicit grammar instruction has potentially raised the participants' awareness of grammar. Second, pragmatic instruction has potentially provided the participants with pragmatic knowledge. Third, the three FFI techniques have engaged the participants in various cognitive processes which potentially catalyzed their language learning and, eventually, language use. Fourth, integrating grammar and pragmatic instruction has potentially fostered each participant's overall communicative competence (in which his/her grammatical competence is subsumed).

Based on the current findings, it is recommended that EFL instructors make use of FFI instruction, as it has proven effective in this particular context. It is also recommended that EFL instructors opt for teaching pragmatics, as instruction has been found to positively affect learners' pragmatic knowledge.

Further research is recommended on the effect of other FFI techniques on other language aspects in both basic and tertiary education. A more diverse sample with a longer instructional interim may improve the generalizability of the current findings.

\section{Acknowledgements}

This manuscript is an extension of the second author's doctoral dissertation per the regulations in force at Yarmouk University, Irbid, Jordan.

\section{Authors' contribution}

All three authors initiated the research, reviewed the related literature, participated in the design of the study, followed the day-to-day details of the data collection and subsequent data analysis, and read and approved the final manuscript. RFB supervised the initial design of the treatment and instruments, performed the statistical analysis, and produced the initial draft of the manuscript. FRA administered the treatment and collected the data. OMS participated in supervising the initial design of the treatment and instruments and helped draft the manuscript.

Competing interests

The authors declare that they have no competing interests.

\section{Publisher's Note}

Springer Nature remains neutral with regard to jurisdictional claims in published maps and institutional affiliations.

Received: 14 July 2017 Accepted: 26 October 2017

Published online: 09 November 2017

\footnotetext{
References

Abadikhah, S., \& Shahriyarpour, A. (2012). The role of output, input enhancement and collaborative output in the acquisition of English passive forms. Journal of Language Teaching and Research, 3(4), 667-676 Retrieved 7 June 2017 from http://www.academypublication.com/issues/past/jltr/vol03/04/11.pdf.

Al al-Bayt University (2015). Retrieved 7 June 2017 from http://web2.aabu.edu.jo/faculties_site/arabic/index.jsp?menu_ id=7\&site_no=100031\&col_id=31\&dept_id=0.
} 
Al-Damiree, R., \& Bataineh, R.F. (2016). Vocabulary knowledge and syntactic awareness as potential catalysts for reading comprehension among young Jordanian EFL students. Journal of Teaching and Teacher Education (University of Bahrain), 4(1), 53-59. Retrieved 7 June from http://journals. uob.edu.bh/JTTE/contents/volume-1073/articles/article-2397.

Al-Qeyam, F. R., Bataineh, R. F., \& Smadi, O. M. (2016). The effect of form-focused instruction on learning and retaining pragmatic knowledge among Jordanian EFL tertiary-level learners. Journal of International Doctoral Research, 5(1), $28-50$.

Assaf, S., Al-Shboul, Y., \& Alodwan, T. (2012). In-service teachers' views of form focused instruction (FFI) and communicative meaning-oriented instruction (MOI): The case of Jordan. European Journal of Social Sciences, 30(10), 79-91.

Austin, J. (1962). How to do things with words. Oxford: Oxford University Press.

Bardovi-Harlig, K., Hartford, B. A. S., Mahan-Taylor, R., Morgan, M., \& Raynolds, D. W. (1991). Developing pragmatic awareness: Closing the conversation. ELT Journal, 45(1), 4-15.

Bataineh, R. F. (2001). Politeness formulas: A cross-cultural study. International Journal of Communication, 11(1-2), 221-233.

Bataineh, R. F., \& Bataineh, R. F. (2006). Apology strategies of Jordanian EFL university students. Journal of Pragmatics, 38(11), 1901-1927.

Bataineh, R. F., \& Bataineh, R. F. (2008). A cross-cultural comparison of apologies by native speakers of American English and Jordanian Arabic. Journal of Pragmatics, 40(4), 792-821.

Bataineh, R. F., \& Mayyas, M. B. (2017). The utility of blended learning in EFL reading and grammar: A case for Moodle. Teaching English with Technology, 7(3), 35-49 Retrieved 20 September 2017 from http://www.tewtjournal.org/ ?wpdmact=process\&did=NTAwLmhvdGxpbms.

Binder, C. (1990). Precision teaching and curriculum-based measurement. Journal of Precision Teaching, 7(2), 33-35 Retrieved 7 June 2017 from http://www.behavior.org/resources/215.pdf.

Binder, C. (1991). Marketing measurably effective instructional methods. Journal of Behavioral Education, 1(3), 317-328.

Binder, C. (1996). Behavioral fluency: Evolution of a new paradigm. The. Behavior Analyst, 19(2), 163-197.

Binder, C. (2003). Doesn't everybody need fluency? Performance Improvement Quarterly, 42(3), 14-20.

Brown, H. D. (2001). Teaching by principles: An interactive approach to language pedagogy. New York: Longman.

Chiesa, M., \& Robertson, A. (2000). Precision teaching and fluency training: Making maths easier for pupils and teachers. Educational Psychology in Practice, 16(3), 297-310.

Chomsky, N. (1980). Rules and representations. New York: Blackwell.

Cutting, J. (2008). Pragmatics and discourse: A resource book for students. London: Routledge.

Dahlen, K., \& Caldwell-Harris, C. (2013). Rehearsal and aptitude in foreign vocabulary learning. The Modern Language Journal, 97(4), 902-916.

Doughty, C., \& Williams, J. (1998). Pedagogical choices in focus on form. In C. Doughty \& J. Williams (Eds.), Focus on form in classroom second Language Acquisition (pp. 197-261). Cambridge: Cambridge University Press.

Ellis, N. (2002). Frequency effects in language processing: A review with implications for theories of implicit and explicit language acquisition. Studies in Second Language Acquisition, 24(2), 143-188 Retrieved 7 June 2017 from http:// www.lextutor.ca/hyp/1/ellis_2002.pdf.

Ellis, R. (2001). Introduction: Investigating the form-focused instruction. In R. Ellis (Ed.), Form-focused instruction and second language teaching (pp. 1-46). Oxford: Blackwell Publishers.

Fotos, S., \& Nassaji, H. (2011). Form-focused instruction and teacher education: Studies in honor of rod Ellis. Oxford: Oxford University Press.

Grice, T., \& Maheen, A. (2007). Oxford English for careers nursing (1): Teacher's book. Oxford: Oxford University Press.

Grice, T., \& Maheen, A. (2009). Oxford English for careers nursing (1): Student's book. Oxford: Oxford University Press.

Gumperz, J. J., \& Roberts, C. (1980). Developing awareness skills in inter-ethnic communication. In Occasional paper 12. Singapore: SEAMEO Regional Language Center.

Guttman, M. (2004). Increasing the linguistic competence of the nurse with limited English proficiency. The Journal of Continuing Education in Nursing, 35(6), 264-269.

Harley, B. (1998). The role of focus-in-form tasks in promoting child L2 acquisition. In C. Doughty \& J. Williams (Eds.), Focus on form in classroom second Language Acquisition (pp. 156-174). Cambridge: Cambridge University Press.

Hernández, T. (2008). The effect of explicit instruction and input flood on students' use of Spanish discourse markers on a simulated oral proficiency interview. Hispania, 91(3), 665-675.

Hernández, T. (2011). Re-examining the role of explicit instruction and input flood on the acquisition of Spanish discourse markers. Lanquage Teaching Research, 15(2), 159-182.

Huang, Q. (2010). Interlanguage pragmatic theory and its implications for foreign language. Journal of Language Teaching and Research, 1(5), 682-684. Retrieved 7 June 2017 from http://www.academypublication.com/issues/past/ j|tr/vol01/05/22.pdf.

Huwari, I. M., \& Al-Shboul, Y. (2015). A study on the perception of Jordanian EFL learners' pragmatic transfer of refusals. Advances in Language and Literary Studies, 6(1), 46-54.

Hymes, D. (1983). Essays in the history of linguistic anthropology. Philadelphia: John Benjamin.

Izumi, S. (2002). Output, input enhancement, and the noticing hypothesis: An experimental study on ESL relativization. Studies in Second Language Acquisition, 24(4), 541-577.

Lingli, D., \& Wannaruk, A. (2010). The effects of explicit and implicit instruction in English refusals. Chinese Journal of Applied Linguistics, 33(3), 93-109.

Long, M. (1991). Focus on form: A design feature in language methodology. In K. De Bot, R. Ginsberg, \& C. Kramsch (Eds.), Foreign language research in cross-cultural perspective (pp. 39-52). John Benjamin: Amsterdam.

Long, M. (2000). Focus on form in task-based language teaching. In R. D. Lambert \& E. Shohamy (Eds.), Language policy and pedagogy: Essays in honor of a. Ronald Walton (pp. 172-192). Philadelphia: John Benjamin.

Long, M., \& Robinson, P. (1998). Focus on form: Theory, research, and practice. In C. Doughty \& J. Williams (Eds.), Focus on form in classroom second language acquisition (pp. 15-41). Cambridge: Cambridge University Press.

Lyster, R. (1994). The effect of functional-analytic teaching on aspects of French immersion students' sociolinguistic competence. Applied Linguistics, 15(3), 263-307.

Lyster, R. (2001). Negotiation of form, recasts, and explicit correction in relation to error types and learner repair in immersion classrooms. Language Learning, 51(1), 265-301. 
McKay, S. (1985). Teaching grammar: Form, function and technique. New York: Pergamon Press Ltd.

Nivis, D. (2013). The role of pragmatics in English language teaching: Pragmatic competence. Academic. Journal of Interdisciplinary Studies, 2(4), 63-70.

Omaggio-Hadley, A. (2001). Teaching language in context. Boston: Heinle and Heinle.

Parviz, M., \& Gorjian, B. (2013). The effect of form-focused instruction (FFI) on teaching English grammar to Iranian students at the intermediate level. International Journal of Lanquage Learning and Applied Linguistics World, 4(4), 450-462.

Rafieyan, V., Sharafi-Nejad, M., \& Eng, L. S. (2014). Effect of form-focused pragmatic instruction on production of conversational expressions. Theory and Practice in Lanquage Studies, 4(8), 1586-1592.

Richards, J., \& Rodgers, T. (2006). Approaches and methods in language teaching. Cambridge: Cambridge University Press. Rutherford, W. (1980). Aspects of pedagogical grammar. Applied Linguistics, 1(1), 60-73.

Sanatullova-Allison, A. (2014). Memory retention in second language acquisition and instruction: Insights from literature and research. The IAFOR Journal of Language Learning, 1(1), 1-13.

Savignon, S. (1976). Communicative competence: Theory and classroom practice. Paper presented at the central states conference on the teaching of foreign languages, Detroit (Michigan), 23 April.

Saville-Troike, M. (2003). The ethnography of communication. Oxford: Blackwell Publishing Limited.

Schmidt, R. (1990). The role of consciousness in second language learning. Applied Linguistics, 11(2), 129-158.

Sharwood-Smith, M. (1993). Input enhancement in instructed SLA: Theoretical bases. Studies in Second Language Acquisition, 15(2), 165-179.

Simpson, B. (1997). A study of the pragmatic perception and strategic behavior of adult second language learners. Language Awareness, 6(4), 233-237.

Spada, N. (1997). Form-focused instruction and second language acquisition: A review of classroom and laboratory research. Language Teaching, 30(2), 73-87.

Spada, N., Jessop, L., Tomita, Y., Suzuki, W., \& Valeo, A. (2014). Isolated and integrated form-focused instruction: Effects on different types of L2 knowledge. Lanquage Teaching Research, 18(4), 453-473.

Spada, N., \& Lightbown, P. (2008). Form-focused instruction: Isolated or integrated. TESOL Quarterly, 42(2), 181-207.

Svalberg, A. M.-L. (2013). Language learning and teaching: Teaching for language awareness. In C. A. Chapelle (Ed.), The encyclopedia of applied linguistics. Oxford: Wiley-Blackwell.

Thornbury, S. (2001). Uncovering grammar. Oxford: Macmillan Heinemann.

Westney, P. (1994). Rules and pedagogical grammar. In T. Odlin (Ed.), Perspectives on pedagogical grammar (pp. 72-96). Cambridge: Cambridge University Press.

Williams, J. (1999). Memory, attention, and inductive learning. Studies in Second Language Acquisition, 21(1), 1-48.

Wolf, M. (2001). Dyslexia, fluency and the brain. Timonium, New Jersey: York Press Inc..

$\mathrm{Yu}, \mathrm{X}$. (2011). Memory base of language and its implication for second language learning. Journal of Communication and Research, 3(2/3), 305-319.

Submit your manuscript to a SpringerOpen ${ }^{\odot}$ journal and benefit from:

- Convenient online submission

- Rigorous peer review

- Open access: articles freely available online

- High visibility within the field

Retaining the copyright to your article

Submit your next manuscript at $>$ springeropen.com 